\title{
Special aspects of ice drilling and results of 5G hole drilling at Vostok station, Antarctica
}

\author{
V.S. LITVINENKO, ${ }^{1}$ N.I. VASILIEV ${ }^{1}{ }^{1}$ V.Ya. LIPENKOV ${ }^{2}$ A.N. DMITRIEV, ${ }^{1}$ \\ A.V. PODOLIAK ${ }^{1}$ \\ ${ }^{1}$ National Mineral Resources University, St Petersburg, Russia \\ E-mail:vvasilev_n@mail.ru \\ ${ }^{2}$ Arctic and Antarctic Research Institute, St Petersburg, Russia
}

\begin{abstract}
This paper documents the drilling of the 5G deep hole at the Russian Vostok station, Antarctica. The hole construction is described and the specifications of the drill and surface drilling equipment are given. The peculiarities of drilling at various depths are considered. Based on the extensive experimental data collected at Vostok station, the processes occurring at the hole bottom are investigated: ice breaking and cutting, bottom cleaning and chip transport, and accumulation of the chips in the screen. The main factors affecting ice-drilling efficiency are the coarseness of ice crystals and the ice temperature. When ice crystal size exceeds $10 \mathrm{~mm}$ the cutting efficiency sharply decreases, and when ice temperature exceeds $-5^{\circ} \mathrm{C}$ the chip transport from the hole bottom and the chip density in the screen are reduced. The drill advance then becomes irregular, slows down and may even be terminated in some cases. Optimal values of the basic drilling parameters (e.g. cutter head rotation rate and drilling fluid flow rate in the circulation system) have been deduced empirically. The designs of the cutter head and circulation system including screens have been significantly modified, allowing the drilling process to proceed at a normal rate even in the vicinity of the subglacial lake surface.
\end{abstract}

KEYWORDS: ice core, ice coring, subglacial lakes

\begin{abstract}
INTRODUCTION
Several deep holes have been drilled at the Russian Vostok station, Antarctica, since 1970. Russian researches played an important role in developing the design and implementation of the thermal drilling equipment that was mainly used before 1993. One of the aims of the deep drilling through the Antarctic ice sheet at that time (when we did not yet know of the existence of Vostok Subglacial Lake beneath the station) was to sample subglacial rocks that required mechanical drilling. For this purpose the drilling complex at Vostok station was re-equipped in 1993, during the 39th season of the Russian Antarctic Expedition (RAE), in order to continue drilling with the electromechanical boring head. The mechanical method has some advantages over thermal drilling, including a higher penetration rate and better icecore quality. The discovery of Subglacial Lake Vostok and the changes in the physical and mechanical properties of ice below $3000 \mathrm{~m}$ required further modifications of the design schedule and drilling operation procedures.
\end{abstract}

\section{G HOLE}

The 5G hole drilling started in 1990 during the 35th Soviet Antarctic Expedition (SAE). The thermal method with cutter heads of type TELGA and TBZS (Kudryashov and others, 1983, 1991; Vasiliev and others, 2007) was used. During the 38th RAE (1993) the hole reached $2775 \mathrm{~m}$ depth.

During the 40th RAE (1995), the 5G-1 hole drilling continued from $2755 \mathrm{~m}$ with the electromechanical drill (Kudryashov and others, 2002; Vasiliev, 2002) and reached $3109 \mathrm{~m}$ depth without difficulty. During the $41 \mathrm{st}, 42 \mathrm{nd}$ and 43rd RAE (1995/96, 1996/97 and 1997/98), the 5G-1 hole drilling continued in the depth interval 3109-3523 m. After the end of seasonal operations in February 1998, drilling was suspended for 8 years and resumed only during the $51 \mathrm{st}$ RAE in January 2005 (Vasiliev and others, 2007), when the drill reached $3650 \mathrm{~m}$ depth. Despite this long hiatus, the hole wall was not distorted owing to the almost complete compensation of the ice pressure by the pressure of drilling fluid along the entire hole.

In October 2007 (52nd RAE), the drill got stuck and was eventually lost close to the hole bottom at $\sim 3666 \mathrm{~m}$ depth. During the 54th RAE (January 2009) after a number of failed attempts to recover the drill, a deviation was made at $\sim 3600 \mathrm{~m}$ depth, and drilling of the new branch hole 5G-2 continued with the same electromechanical drill.

The Russian explorers unsealed Subglacial Lake Vostok at $3769.3 \mathrm{~m}$ depth on 5 February 2012 (57th RAE). Just after the lake unsealing, the water level in the hole rose to $\sim 3385 \mathrm{~m}$ and then fell to an equilibrium depth of $3427 \mathrm{~m}$, where the water froze. During the 58th and 59th RAE, coring of the frozen water in the hole was undertaken. As drilling advanced, the drill progressively deviated from hole $5 \mathrm{G}-1$, and at $3458 \mathrm{~m}$ depth the new branch hole 5G-3 completely separated from the former one and the fulldiameter replicate core of meteoric ice was obtained. By February 2014, 5G-3 hole had reached $3724 \mathrm{~m}$ depth. The inclination of $5 \mathrm{G}-3$ hole at this depth is $\sim 3^{\circ}$, which is $2^{\circ}$ less than that of $5 \mathrm{G}-2$ hole.

The deep hole at Vostok station has a complex multizone structure (Fig. 1). The casing with inner diameter of $165 \mathrm{~mm}$ was installed down to $120 \mathrm{~m}$ depth. Down to $2502 \mathrm{~m}$ the drilling continued with thermal drill TBZS-152, and the minimal diameter of the hole was $153 \mathrm{~mm}$. The drill then got stuck during the pulling-out operation and was lost at $\sim 2250 \mathrm{~m}$ depth. The new branch hole 5G-1 was started by deviation at $2230 \mathrm{~m}$ depth with the thermal drill 


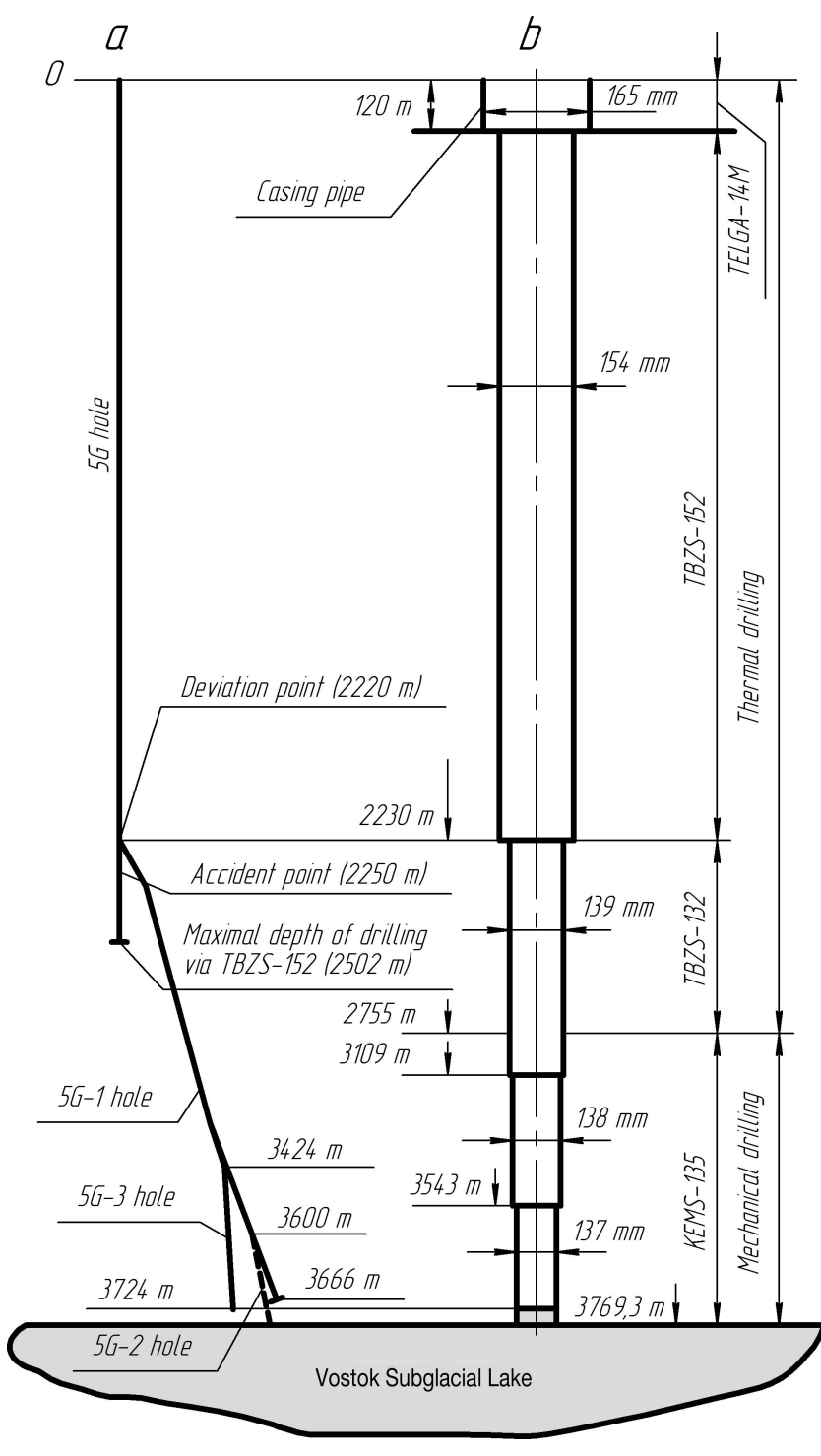

Fig. 1. 5G hole diagram: a. vertical section; b. hole structure.

Table 1. Specifications of the drilling complex

\begin{tabular}{lc}
\hline Shelter & \\
Length & $18 \mathrm{~m}$ \\
Width & $4 \mathrm{~m}$ \\
Height & $3 \mathrm{~m}$ \\
Height of drilling mast & $15 \mathrm{~m}$ \\
Power consumption & \\
D.c. generator & $20 \mathrm{~kW}$ \\
Winch electromotor & $20 \mathrm{~kW}$ \\
Heating system & $12 \mathrm{~kW}$ \\
Light & $5 \mathrm{~kW}$ \\
Average rate of drilling-tool round & $0.7 \mathrm{~m} \mathrm{~s}^{-1}$ \\
trip when hole depth is $4000 \mathrm{~m}$ & \\
Carrying cable & \\
Outer diameter & $16 \mathrm{~mm}^{-1}$ \\
Breaking load & $97 \mathrm{kN}^{\text {Number of electrical conductors }}$ \\
Unit resistance of one conductor & 8 \\
& $9 \Omega \mathrm{km}^{-1}$ \\
\hline
\end{tabular}

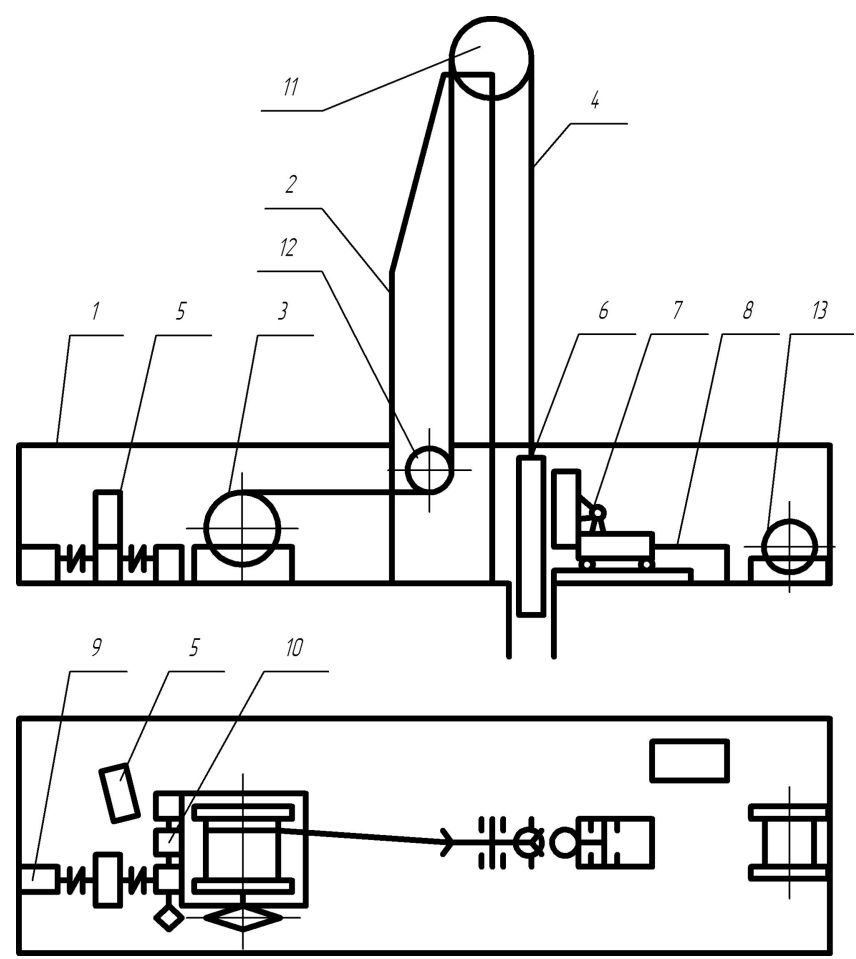

Fig. 2. Drilling complex at Vostok station: 1. shelter; 2. drilling mast; 3. drill winch; 4. carrying cable; 5 . control panel; 6. drill; 7. device for drill assembly mounting; 8. d.c. generator; 9. main transmission of winch; 10. transmission of uniform feed; 11 . upper roller; 12. lower roller; 13. geophysical winch.

TBZS-132, equipped with a cutter head with outer diameter $132 \mathrm{~mm}$. The hole drilled with TBZS-132 initially had a minimal diameter of $133 \mathrm{~mm}$ in the depth range 2200$2755 \mathrm{~m}$. Prior to mechanical drilling, the diameter of this part of the hole was enlarged to $139 \mathrm{~mm}$ by the electromechanical drill. During mechanical drilling, hole reaming was continued on a regular basis, resulting in a step-like structure of the hole.

The total volume of the drilling fluid (a mixture of jet fuel TS-1 and Freon F-141b) filling the hole is $60 \mathrm{~m}^{3}$. The level of drilling fluid (average density $\sim 905 \mathrm{~kg} \mathrm{~m}^{-3}$ ) was at $34 \mathrm{~m}$ depth by 5 July 2014 .

\section{FACILITIES}

\section{G-1 drilling complex}

The 5G-1 drilling complex at Vostok station (Fig. 2; Table 1) comprises shelter (1), drilling mast (2), winch (3), carrying cable (4), control panel (5), drill assembly (6), a device for drill assembly mounting (7) and d.c. generator (8) supplying the winch. The systems of drill assembly supply and control can operate at $-60^{\circ} \mathrm{C}$ and up to $40 \mathrm{MPa}$ of pressure in the hole filled with non-freezable fluid.

\section{Casing}

The upper part of the hole from the surface to $120 \mathrm{~m}$ depth is cased with plastic pipes similar to ones used in Greenland and at Dome C, Antarctica. The pipes were installed prior to mechanical drilling when the hole depth was $2755 \mathrm{~m}$. The lower end of the casing column had an aluminium shoe which was heated during placement of the pipe in the casing seat. After the column was embedded to $0.5 \mathrm{~m}$ depth, the shoe heating was stopped and the lower end of 
Table 2. Specifications of the drill assembly KEMS-132

\begin{tabular}{lc}
\hline $\begin{array}{l}\text { Cutter head diameter } \\
\text { Outer }\end{array}$ & \\
Inner & $132-138 \mathrm{~mm}$ \\
Core barrel length & $3 \mathrm{~m}$ \\
Drive motor & \\
Power voltage & $\sim 220 \mathrm{~mm}$ \\
Motor power & $1000 \mathrm{~W}$ \\
Rotor rotation rate & $2800 \mathrm{rpm}$ \\
Head rotation rate & $120-220 \mathrm{rpm}^{2}$ \\
Mechanical rate of drilling & \\
In ice & up to $5.5 \mathrm{~mm} \mathrm{~s}^{-1}$ \\
In subglacial rock & up to $0.4 \mathrm{~mm} \mathrm{~s}^{-1}$ \\
Total length & $13 \mathrm{~m}$ \\
Weight & $240 \mathrm{~kg}$ \\
\hline
\end{tabular}

the pipe became firmly frozen in ice. An ice plug $\sim 2 \mathrm{~m}$ high was then created above the shoe to ensure a good sealing between the casing and the permeable firn, and then subsequently re-drilled.

\section{Electromechanical drill}

Standard electromechanical coring equipment KEMS-132 (Fig. 3; Table 2) comprises head (1), core barrel (2), chip chamber including chip filter (screen) (3), reducer (4), power motor (5), pump of reverse circulation (6), anti-torque system (7), hammer unit (8), current collector (9), cable end (10) and carrying cable (11). The electromechanical drill operates as follows. The rotation is transmitted from electromotor rotor (5) via reducer (4) to the core barrel with a cutter head fixed on it (1). The produced ice chips are flushed into the chip chamber (3) by drilling fluid and stored in the filter. Drilling fluid flowing up via central reducer shaft bores and drive motor is pumped out in the annulus by the pump (6). The anti-torque system (7), contacting the hole walls, prevents the upper part of the drill assembly from rotating during drilling.

\section{PERFORMANCE}

At the beginning of the mechanical drilling the average penetration per run progressively lengthened (Fig. 4) as the team's expertise increased, then the drilling operations became regular and resulted in an average penetration rate of $2.8 \mathrm{~m}$ per run (drilling operations cycle includes the drill preparation procedures, lowering of the drill assembly in the hole, coring, core breaking, pulling out the drill, extraction of core and chips and other auxiliary operations). Starting from $2930 \mathrm{~m}$ depth, the drilling progressively became irregular. Unexpected sticking of the cutter head occurred even at a low rate of penetration $\left(0.3 \mathrm{~mm} \mathrm{~s}^{-1}\right)$. Simultaneously, the drilling penetration per run progressively decreased. Increasing the fluid column weight by adding the densifier at the beginning of the 41 st RAE season ensured sustainable drill advance; nevertheless at the end of the season, despite all the measures undertaken, the drilling penetration rate began to dwindle and finally the drilling almost stopped. In the next season the design of the drill assembly had been modified and operations were resumed. By the end of the season, however, penetration per run started to decrease again up to a dead stop. The maximal

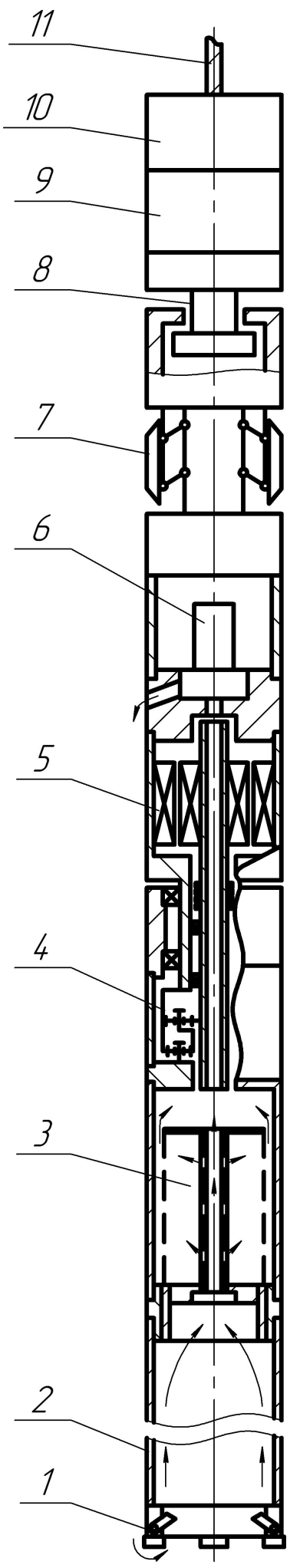

Fig. 3. Scheme of electromechanical coring drill KEMS-132. 1. head; 2 . core barrel; 3 . ice chip chamber; 4 . reducer; 5 . power motor; 6. pump; 7. anti-torque; 8. hammer unit; 9. current collector; 10 . cable end; 11 . carrying cable.

penetration per run dramatically decreased for no apparent reason; the cutter head often got stuck in sludge at the start of the drilling run.

Many projects have faced severe problems in the course of deep hole drilling in Greenland and Antarctica even at depths around $2500 \mathrm{~m}$. Below $3000 \mathrm{~m}$, the complications became so serious that drilling operations almost stopped. 


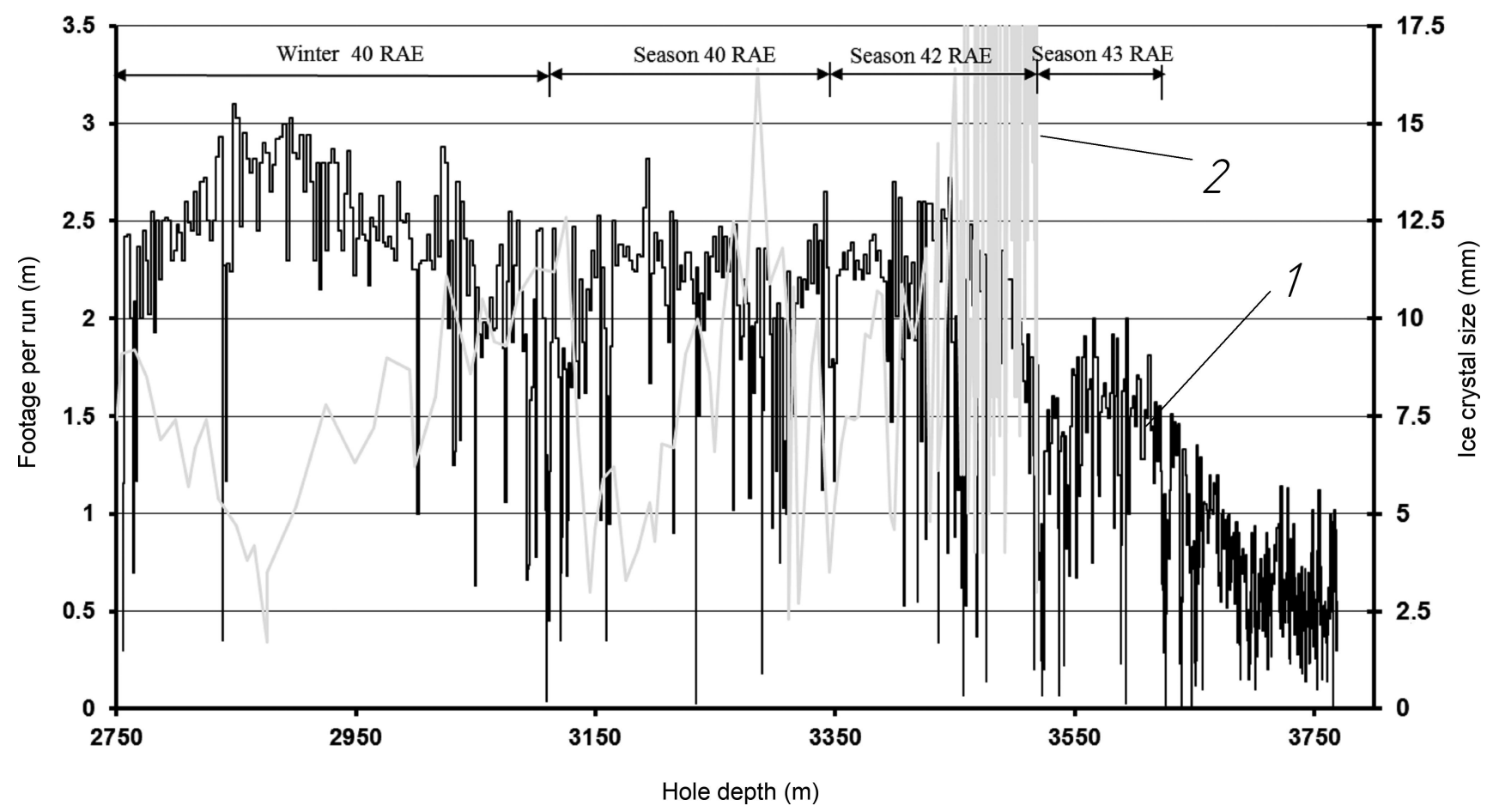

Fig. 4. Results of electromechanical drilling of 5G-1 hole at Vostok station. Curve 1: penetration per drilling run; curve 2: ice crystal size (Lipenkov and others, 2007). Depth intervals drilled during different RAEs are indicated at the top.

This phenomenon has been called 'a problem of warm ice drilling' because the ice temperature increased with depth. An example of such complications is the decrease in penetration per run during the EPICA Dome $\mathrm{C}$ drilling (Augustin and others, 2007a,b). The decrease in average penetration started when a depth of $2500 \mathrm{~m}$ had been reached; after that, the penetration rate significantly decreased and at $3000 \mathrm{~m}$ depth the drilling almost stopped. The case study showed that, due to high temperature, the ice melted and refroze, sticking on the drilling head cutters and body. Nevertheless, we consider it incorrect to associate drilling problems that occur at great depths only with the elevated temperature of the ice. At Vostok, at $2700 \mathrm{~m}$ depth the ice temperature is $-24^{\circ} \mathrm{C}$, and at $3600 \mathrm{~m}$ depth is slightly above $-5^{\circ} \mathrm{C}$ (i.e. $\sim 2.5^{\circ} \mathrm{C}$ below the pressure-melting point). It progressively increases with depth, but the change in penetration per run has a periodic character. The drillingfailure case study revealed a correlation between the penetration rate and the size of ice crystals and physical properties of ice (Lipenkov and others, 2007).

It has been shown that all depth intervals in which major drilling problems occur correspond to relatively coarsegrained ice (Fig. 4). The correlation between drilling penetration per run and crystal size is evident. From 2755 to $2840 \mathrm{~m}$ depth the drilling penetration per run progressively increases as ice crystal size decreases. Below this, crystal size increases while the drilling penetration per run decreases. At $3080 \mathrm{~m}$ depth, crystal size exceeds $10 \mathrm{~mm}$ and the drill performance is extremely irregular down to $3120 \mathrm{~m}$ depth. At $\sim 3480 \mathrm{~m}$ depth the ice crystal size exceeds $20 \mathrm{~mm}$ and drilling penetration rate steadily approaches zero.

To determine the causes of the drilling failures the system components should be studied. The work of the drill assembly consists of the following essential steps: (1) ice cutting; (2) hole bottom cleaning and chip removal; (3) collection of the chips in the filter. The three steps are interdependent. Drill performance at the hole bottom is mainly influenced by the following: geometrical features of the drill cutters; drill head rotation rate (rate of cutting); cutting depth; the filter and the chip transport channel designs; specifications of the pump that drives the drilling fluid circulation at the hole bottom.

Study of the ice-cutting and chip-formation processes has revealed that, with the same rates of drill head rotation and ice cutting, the chips become smaller when the average ice crystal size increases. The drilling of fine-grained ice produces chip particles $1-2 \mathrm{~mm}$ in size, even if the penetration rate is $<1.4 \mathrm{~mm} \mathrm{~s}^{-1}$. When cutting the monocrystalline ice, the chip particles are smaller $(<0.5 \mathrm{~mm})$ and contain a large fine-powder fraction. Once the fine chips are collected in the filter they may form an almost impermeable layer on the filter screen. This layer, even if it is thin, creates high resistance for the drilling fluid flow. It results in loss of the flow and consequently in the formation of the icy plug on the cutters which eventually stops the drilling. The ice plug formation is additionally facilitated by the elevated temperature of the ice which promotes ice melting and refreezing on the surface of the cutters.

The fine-grained chips are considered to be the main cause of the decrease in drilling penetration per run due to an increase in hydraulic resistance in the filter in the chip chamber. On the other hand, a spontaneous cessation of drilling primarily occurs as a result of insufficient drilling fluid flow rate causing the icy-plug formation on the drill cutters. For drilling in rocks, the recommended chip concentration in the fluid flow is $<5 \%$. For ice drilling the fluid flow rate is $\sim 40 \mathrm{~L} \mathrm{~min}^{-1}$ in the Russian, as well as the EPICA, drill assembly. With a penetration rate of $1.7 \mathrm{~mm} \mathrm{~s}^{-1}$, the concentration of chips in drilling fluid should be $\sim 1.5-2 \%$.

Penetration per run started to decrease at $3450 \mathrm{~m}$ depth (Fig. 4). Decreasing the cutting rate did not bring positive results. Every time the chip density in the filter reached a 
critical level, the settling of cuttings on the cutter head occurred and the drilling stopped before the chip chamber had been filled. On the other hand, during the hole reaming it was possible to collect in the chip chamber a great amount of chips corresponding to 2.8-3.0 m of drilling penetration with ice-core recovery. We explain this by the low concentration $(\sim 0.15 \%)$ of ice chips in the fluid flow during the reaming as compared to the ice-core drilling process.

Thus, it can be concluded that the best solution for increasing the penetration per run below $3000 \mathrm{~m}$ is to increase the fluid flow rate which will result in reduction of the chip concentration in the drilling fluid. This conclusion had been reached by the end of the 43rd RAE (January 1998), but due to the hiatus in drilling and after the drill became stuck during the 52nd RAE, the proposed solution was implemented only after the deviation and continuation of the 5G-2 drilling in the 56th RAE.

The efficiency of chip removal from the hole bottom depends not only on the drilling fluid flow rate but on the cutter and chip transport channels design. To intensify chip removal from the hole bottom, the cutter head design had been modified so as to direct almost all the flow towards the cutter area and triple the size of the chips.

The cutter head (Fig. 5) is a combination of the three onecutter bits. Each cutter accounts for one-third of the entire width of the cut. The cut layer is three times thicker than that cut with standard cutters, resulting in an increase in chip size and consequently in the drilling penetration per run. In addition, the coarse-grained chips have a smaller total surface area, which reduces the risk of chip agglomeration, particularly at depths exceeding $3000 \mathrm{~m}$ where the ice temperature is high.

The persistent decrease in drilling penetration per run below $3650 \mathrm{~m}$ depth, even with a drilling fluid flow rate of $120 \mathrm{~L} \mathrm{~min}^{-1}$ and the new cutter head, is associated with a progressive increase in ice temperature. At these depths the ice temperature is slightly below $-5^{\circ} \mathrm{C}$, i.e. presumably only $2.5^{\circ} \mathrm{C}$ below the melting point. The elevated temperature of ice results in the formation of compacted ice chip plugs, even in cases of minimal chip compression (e.g. at the entrance to the central chip-collecting tube and in the filter). This leads to fluid circulation ceasing and accretion of chips above the cutter head. A similar phenomenon can be observed when you make snowballs with slightly melted snow. We have managed to cope with this obstacle by introducing a major modification to the chip collector filter design. The most efficient configuration was achieved by combining the standard filter of the KEMS-132 drill assembly with the EPICA one. The fluid flow in this case was organized so that the chips were uniformly distributed in the volume. Nevertheless the density of chips in the chip chamber was twice as low as it had been at depths above $3650 \mathrm{~m}$. Even though the drilling penetration per run was getting low, the drill performance became steady and proceeded without unexpected stops.

After the Vostok Subglacial Lake unsealing, re-drilling of the deep hole was implemented with the modified drill assembly. The graph of the penetration per run (Fig. 6) demonstrates the efficiency of the measures taken. The coring of refrozen ice started at $3427 \mathrm{~m}$. Deviation of the drill from the initial hole filled with refrozen ice gradually increased with depth. At $3458 \mathrm{~m}$ the deviation was completed and the new 5G-3 branch hole started. The continuation of 5G-3 hole drilling allowed a replicate core

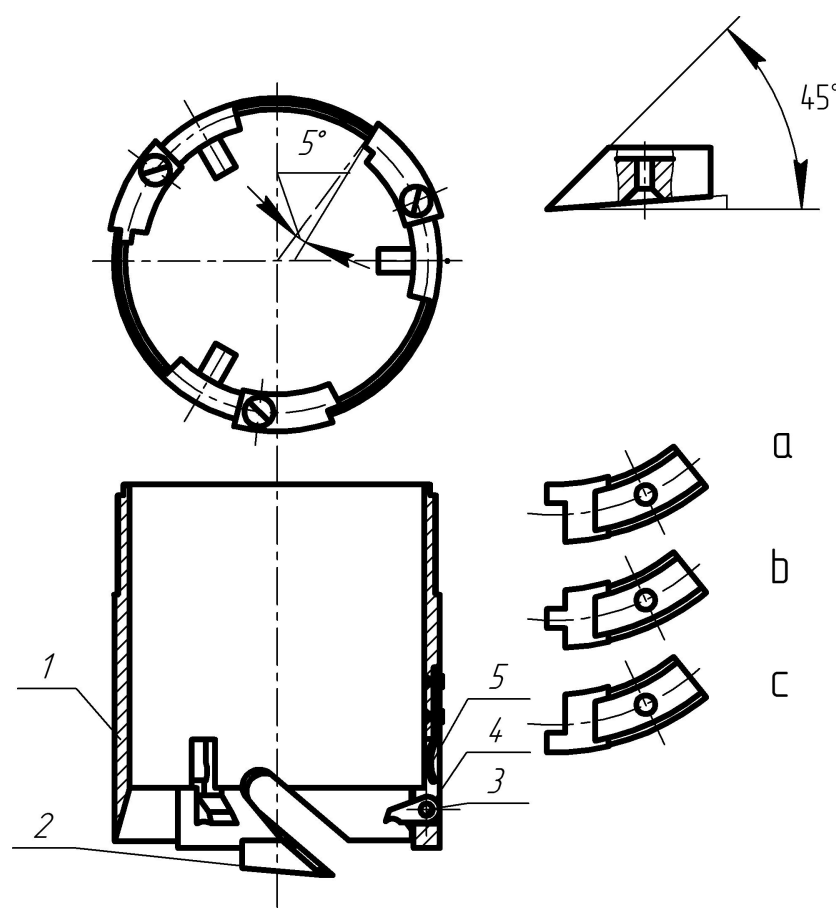

Fig. 5. Retrofit cutter head adjusted for 'warm' coarse crystalline ice drilling: 1 . head body; 2 . blades ( $\mathrm{a}, \mathrm{b}, \mathrm{c}$ : blade modifications); 3. axe of core-cutter trigger; 4. core-cutter trigger; 5. prong.

to be obtained with essentially the same ice texture as observed in the 5G-1 core.

Drilling efficiency was constantly two to three times higher than it had been during previous drilling at these depths prior to the Subglacial Lake Vostok unsealing. Nevertheless, beginning at $3650 \mathrm{~m}$ depth, penetration per run started to drop and below $3700 \mathrm{~m}$ decreased to $0.8 \mathrm{~m}$. Thus, within this depth interval the tendency of the penetration per run to decrease was similar to that observed during the previous drilling, but the regularity of the drill performance improved and drilling efficiency significantly increased.

\section{CONCLUSION}

The experimental data obtained during deep drilling at Vostok station have helped to better understand the drilling process at great depths close to a subglacial water body. The adjustment of the drill assembly design and the drilling procedures has allowed almost the same drilling efficiency to be maintained below $3000 \mathrm{~m}$ as at shallower depths. This is proved by the results of the 5G-3 hole drilling implemented after the Subglacial Lake Vostok unsealing.

Using the extensive set of obtained experimental data, we identified the main factors that influence the efficiency of drilling and proposed ways to cope with complications that occur in the course of ice coring in the basal strata of the thick polar ice sheets.

\section{ACKNOWLEDGEMENTS}

The Russian Antarctic Expedition provided the logistic support for drilling operations at Vostok station. The work was financially supported by the Russian Science Foundation, grant 14-27-00030. We thank two anonymous reviewers for valuable comments. 


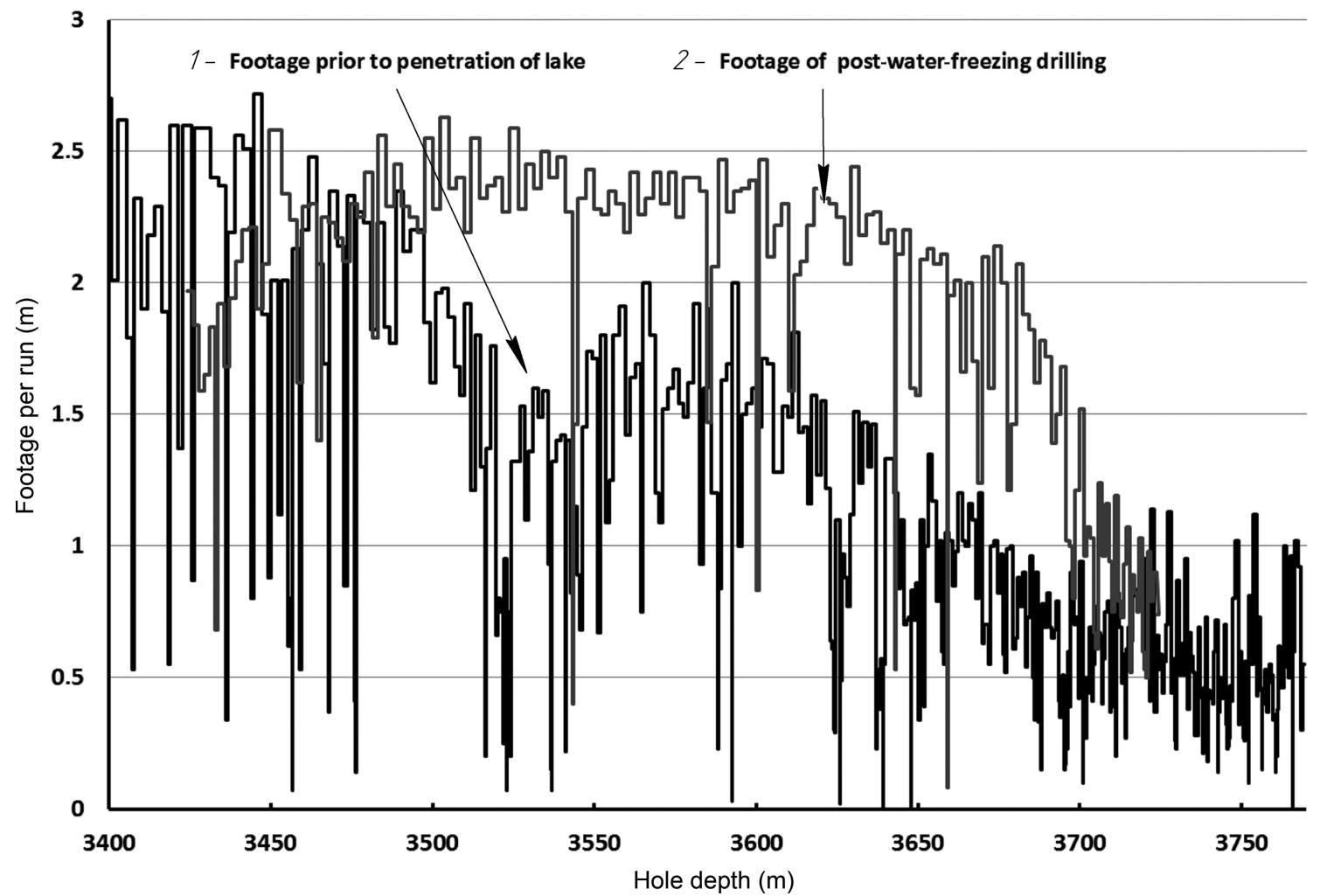

Fig. 6. Penetration per run in 5G-1, 5G-2 and 5G-3 holes. Curve 1: penetration per drilling run in 5G-1 and 5G-2 holes (before Subglacial Lake Vostok unsealing); curve 2: penetration per run in 5G-3 hole (after the unsealing).

\section{REFERENCES}

Augustin L and 6 others (2007a) Drilling comparison in 'warm ice' and drill design comparison. Ann. Glaciol., 47, 73-78 (doi: $10.3189 / 172756407786857820)$

Augustin L, Panichi S and Frascati F (2007b) EPICA Dome C 2 drilling operations: performances, difficulties, results. Ann. Glaciol., 47, 68-72 (doi: 10.3189/172756407786857767)

Kudryashov BB, Chistyakov KV and Morev VA (1983) Burenie lednikovogo pokrova Antarktidy teplovym sposobom [Thermal drilling in Antarctic ice sheet]. In 25 let Sovetskoi Antarkticheskoi Ekspeditsii [25th Anniversary of the Soviet Antarctic Expedition]. Gidrometeoizdat, Leningrad, 149-158

Kudryashov BB, Chistyakov VK and Litvinenko VS (1991) Burenie skvazhin $v$ usloviah izmenenia agregatnogo sostoyanya gornikh porod [Drilling in conditions of rock aggregate changes]. Nedra, Leningrad
Kudryashov BB and 9 others (2002) Deep ice coring at Vostok Station (East Antarctica) by an electromechanical drill. Mem. Natl Inst. Polar Res., Special Issue 56, 91-102

Lipenkov VY, Poliyakova EV, Duval P and Preobrazhenskaya AV (2007) Osobennosti stroeniya antarkticheskogo lednikovogo pokrova $v$ rayone stantsii Vostok po resultatam petrostrukturnikh issledovaniy ledianogo kerna [Internal structure of the Antarctic ice sheet in the vicinity of Vostok Station from the deep ice core thin sections studies]. Probl. Arkt. Antarkt., 76, 68-77

Vasiliev NI (2002) Some features of ice drilling technology by a drill on a hoisting cable. Mem. Natl Inst. Polar Res., Special Issue 56, 136-141

Vasiliev NI and 8 others (2007) Deep drilling at Vostok Station, Antarctica: history and recent events. Ann. Glaciol., 47, 10-23 (doi: 10.3189/172756407786857776) 